\title{
LEADERSHIP AND DECISION MAKING PROCESSES IN MOZAMBIQUE: GOVERNANCE OF SAMORA MACHEL - 1975/1986
}

\author{
António Hama Thay ${ }^{2}$
}

\section{Introduction}

The Republic of Mozambique is located in the southern hemisphere between the latitudes of Io degrees, 27 minutes South and 26 degrees, 52 minutes South, and it also belongs to the Eastern Hemisphere between the meridians of 30 degrees and 12 minutes East and 40 degrees and 5I minutes East. The Mozambican state is an integral part of the territory of Mozambique whose independence was proclaimed on June 25, I975 as The People's Republic of Mozambique and later, in I990, the Republic of Mozambique (Dos Muchangos 1999).

Inspired by the impact of the measures taken by the maximum direction of the Frente de Libertação de Moçambique (FRELIMO), while in charge of the Mozambican government after independence, this thesis describes the impact of leadership in strategic decisions discussed here in the form of case studies. One of the most prominent topics of interest currently in the country is the political leadership and strategic decision processes. This is due, not only to the significant implications of the measures taken in the post-independence period, but also to the controversy generated as the result of its impact on the present scenario and prevailing situations, such as

I This article is part of a doctoral thesis submitted as a partial fulfillment of the PhD Degree on Business Administration (Management) at Commonwealth Open University, in 2016.

2 Faculty of Economics, Universidade Eduardo Mondlane. Maputo, Mozambique. E-mail: ahtpoli2013@yahoo.com.br 
economic dependence, insufficient qualified human resources and incipient public policies.

Thus, the role of leadership in decision-making and its impact is the main subject of this study, which is carried out based on qualitative and descriptive researches, involving seven case studies and further analyses of the processes of privatization of three companies engaged in processing (cashew industry) and services (Mozambique Railways). The research seeks to determine, also, the role of the leadership in the implementation of government management processes arising from the socio-economic, business and political-military dynamics, as well as from regional and international contexts, that occurred in the post-independence period of Mozambique, namely: nationalizations, closure of the border with Southern Rhodesia, now Zimbabwe, communal villages, Prospective Indicative Plan (PPI), and privatizations.

\section{Profile Framework and Leadership in the Governance of Samora Machel: 1975-1986}

The government of Samora Machel, which covered the period of I975-I986, is considered by many to be a decade of intense political leadership. His personal profile and the resulting mode of action emerge as key factors in assessing the type of interaction between different moments that dictated his unique experience as head of state and of Mozambican society. Ribeiro (I995) confirms that Samora's personal characteristics and modes of action, as a ruler, include more repercussions of his personality rather than of ideological references enshrined in literature, such as marxism, capitalism, democracy, or liberalism, to evaluate the governance during that period.

Samora Machel's approach to leadership and governance has become one of the main focuses in the organization of political and social thought in Mozambique. In this regard, Ribeiro (I995) clarifies that, lately, the common sense discourses tend to attribute to Samora Machel the creation of a unique sense of political legitimacy in Mozambique, as if he ought to have opened the eyes and the heads of Mozambicans to what was their dignity as a community with the right to live independently.

In an effort to analyze governance, Christie (1996) chose to split the analysis between internal and external dynamics. According to the author, the first internal dynamic was characterized by an autocratic and populist policy. In this aspect, the author observed in urban areas (towns and cities) the use 
of guerrilla's methods and the commitment to promote the country's development on a socialist basis, suppressing any internal dissent. To that end, Machel adopted measures such as the nationalization of health, education, justice, and rented houses. For rural areas, he conducted programs aimed at rural socialization, personally getting involved in a rice harvesting campaign.

According to Christie (1996), other domestic actions which had popular support and were considered to be important and of profound impact were the population census in I980, and the substitution of the colonial currency for a new one, the Metical. Other popular policies were the "offensives" in favor of increased productivity and against corruption, often advertised in large rallies, with great participation.

It should also be noted that few of these campaigns were successful and, in part, caused the abandonment of the country by large numbers of residents of foreign origin, which led to the temporary shutdown of many companies, and later, for lack of management capacity, to the collapse of many industries, such as the textile, metallurgical, and chemical. The list also includes measures that were considered unpopular, such as the incarceration in "re-education camps" of Jehovah's Witnesses, the "unproductive" and prostitutes, as well as the placement in remote locations of young people with higher education with the stated objective of developing scarcely populated regions.

In the external dynamic, Samora's governance performance is considered relatively successful with respect to his ability to use politics to garner friendships and support for Mozambique. The search for partnerships included not only traditional "friends" of Mozambique, but also the countries of the Soviet bloc; the neighbors in a regional integration front (SADCC), extending even to "enemies", including the leaders of Britain, Margaret Thatcher; of the USA, Ronald Reagan, and of South Africa, Pieter Botha with the Nkomati Accord (Veloso 20I3). Despite the efforts made in order to reverse the situation by trying to slow the centralized policy, Samora's government failed to sustain the war, and the failure of the socialization of policy and war itself led the government of Samora Machel to an economic collapse.

Ribeiro (I995), through the employment of social representations, studied the leadership and governance of Samora Machel on the basis of a model with three categories: (i) personality and capabilities; (ii) the exercise of authority; and (iii) social concerns. The category called personality and capabilities has to do with the personal attributes conferred upon the great leaders that have limited (or that limit) his political action. The second, exercise of authority, relates to the expressions to which the social actors resorted 
to evaluate the way that the head of state interacts (or interacted) with societies, with reference to a dialectic that oscillates between the approach to a more authoritarian model or to a more contractual model. The third category, refers to the social concerns, and results from common sense assessments that allow to check to what extent the exercise of power by a certain leader benefited or harmed, or is likely to benefit or could harm, people's lives, particularly the lives of the most vulnerable communities.

In Max Weber (Bennis 2004) conceptual approach, the personality profile of Samora Machel seems to identify the exercise of the charismatic type of power legitimacy. However, it is possible to find identitarian characteristics of leaders, according to Paul Hersey and Kenneth Blanchard's (20I2) Situational Leadership theory, that show that the maturity of each manager is related to his ability and willingness to accomplish something. It is a management and leadership model ideal for times of crisis, where the difficulties are minimized and the objectives of the corporation are achieved. That is, the dimension of leadership effectiveness is directly linked to the leader's ability to adapt according to his maturity level, and thus offers the environment and adequate resources for the leader to develop and carry out the proposed tasks.

\section{Nationalization of the Rented Houses in Mozambique: Decision Process}

The nationalization of the houses is a milestone in the history of independent Mozambique. The goal was to change ownership of the housing stock (housing for accommodation, trade, industry and services) and, consequently, the economic activities of the private sector and the social composition of the population living in urban areas. The decision to nationalize the houses was announced to the public on February 3, 1976. According to the speech made by Samora Machel, the date of the announcement of policy decisions for the benefit of the masses was purposeful. Such decisions have been described by the President as "[...] important revolutionary measures" (Tempo I976).

Citing some parts of the speech of the first President of the Republic, published in the magazine Tempo (I976, I9) as concerns the symbolism of the date, as can be observed:

We would say that February 3 rd is the day that summarizes the sacrifice of the whole people. Through the sacrifice of President Eduardo Mondlane, we evoke the sacrifices of the thousands and thousands 
who fell in prisons, under torture, under bombardment, the soldiers who fell while carrying out various tasks, to be what we are today.[...] On February 3, the colonialist enemy, allied with international imperialism, stabbed us in the back... It was as if we ripped out the heart from behind ... The 3rd of February is the day that the enemy has laid the stone of great size that sustained and symbolized our determination. [...] February the 3 rd was both an important time ... point of cleavage ... It is after February 3 that we finished with false alliances, artificial and superficial friendships, friendships through secondary and petty things. We have deepened our line and we say: only, only united by a correct line, by an ideology totally at the service of the people, at the service of the Revolution, we will be able to defeat the enemy no matter how strong he is.

\section{The Communal Villages}

The human geography of Mozambique, within the colonial repression model, is of a scattered population, living as far as possible from the center of decision. This phenomenon is exacerbated by low population density. This is the economic justification for the communal village, for the better organization of the Party, as well as for schools, hospitals, energy, and economic systems. The communal villages were created by reasons related to the development of the countryside. Several theorists like Medeiros (1989), the "project" and the activities to build and concentrate the population in villages took place, mainly, between 1976 and mid-i986.

According to documents of the Second National Conference of Ideological Work (DTIP - II National Conference of the Ideological Work I978, 27), the communal villages are defined as "[...] the core of the rural socialization, are an essential element for building the material and ideological bases necessary for the transition to a socialist society". Citing documents of the 8th Session of the Central Committee of FRELIMO (I976, 88), about the plan of communal villages to be implemented:

So, if initially the communal village consists mainly of a production sector and a politically organized habitational sector, it would gradually organize appropriate places for various activities, in particular for administration tasks and production control, people's shop or consumer cooperative, school, health post, child day care/nursery, tree-lined streets in the communal village and roads leading to other villages, places for storage of goods and collective instruments, craft center and small industries, cultural and Gimnodesportivo sector, gardens and green spaces. 
The Prospective Indicative Plan describes the following aspects related to the plan of communal villages: communal village as one of the key tasks in agricultural development and in the component of rural socialization; and provision of support and assurance to water supply and self-help housing as a component of social development, thus increasing the standard of living of the people. It would allow a territorial organization of the population in the countryside to improve housing conditions - housing structure and water supply (FRELIMO i976).

According to Mosca (20II), the communal villages were a responsibility of local authorities, with resources being allocated in the budgets of provincial governments for the construction of such villages. The organization of collective production in the communal village (economic basis) was carried out through cooperative or state enterprises. Shortly after the start of its implementation, it was necessary to create a National Commission of Communal Villages (CNAC), subordinated directly to the President of the Republic. This decision was supported by the Economic and Social Directives of the Third Congress of FRELIMO. The following quote describes the reasons for the commission's creation, according to the Presidential Decree I/78 of March 2nd (Mozambique I978, 439): "However, detect errors and weaknesses that are manifested in particular by the dispersion and duplication of efforts, in the absence of structures at various levels, the blurring of powers, in the absence of an instrument to ensure the centralized direction of the process".

The CNAC had as an objective the management (direction, planning and control) of economic and social development of communal villages and should "[...] coordinate the activities of the state apparatus as such for the communal villages" (Article 3, Presidential Decree I/78 March 2nd). The creation of the Commission was supported by the President's office. It had some privileges, such as: close collaboration with the National Planning Commission; the director of the CNAC had full powers to define the needs of the newly created organism, including the staffing (staff appointments authority), material and financial resources; a Budget Allocation Authorization for the commission's functioning, to be secured by the Minister of Finance; and direct subordination to the President of the Republic.

After the creation of communal villages, in I979 the Office for the Organization and Development of Agricultural Cooperatives was created directly under the Ministry of Agriculture. This office had the duty to support the realization of the economic performance of communal villages as a way of contributing to economic independence. Selecting the location of a village 
was always a challenge because it required checking the habitable natural conditions. According to the magazine Tempo (I977, 42-47), some essential conditions to determine the sites to implement communal villages are:

Fertile soil for agricultural activities; access to surface water (example: rivers, lakes etc.) or groundwater; an expansion zone (this refers to a vast land with the possibility for the expansion of the village); proximity to major roads for the transport of "marketable" produce; and the need to connect the communal villages to the main roads through "feeding roads".

\section{Privatizations' Decision-Making Process in Mozambique}

The creation of the National Cashew Company of Mozambique (EE) was done in accordance with decisions taken at the 3 rd Congress of FRELIMO. They aimed at successfully establishing a strong state sector, through the domination of "key" industries, as was the case of the cashew industry. With the creation of the State Enterprise of Cashew, the activities of seven companies were "liquidated" through the integration of their employees and the transfer of their assets' values to the State Company. The following cashew companies were nationalized by Decree 8/79 of June 3oth: INCABEL - Indústrias de Caju da Beira, Limitada; CAJUCA - Sociedade Industrial de Caju e Derivados, S.A.R.L - Caju Industrial de Moçambique, S.A.R.L; PROCAJU - Produtos de Caju, Limitada; Indústria de Castanha de Caju (Manjacaze) Limitada; Spence \& Peirce (Indústrias de Caju), S.A.R.L; and SACOOR \& TAVARES, Limitada.

The privatizations decision-making process in Mozambique proceeded taking into account the sequence of events in 1978 related with the creation of the Commission to Reorganize the Cashew Industry; in I979, with the extinction of the Commission to Reorganize the Cashew Industry and creation of the National Cashew Company of Mozambique, State Enterprise (E.E.), and in 1994 with appointment of a Commission to Implement the Privatization of the National Cashew Company of Mozambique.

Due to the low performance of the economy, registered since I98I, the privatization of the cashew industry and other companies occurred under the enterprise restructuring program. This restructuring was part of the Economic Rehabilitation Programme. As part of the program, state intervention, regarding the economic component, would be "resized" in order to improve 
the functioning of markets. The privatization of this sector, and of much of the economic activity, included increased participation of the private sector, increased quality of products and services, increased and diversification of supply, job creation, and incentives to foreign investment.

Citing the former Minister, Pascoal Mocumbi (Mocumbi 20I3), in an interview published in the weekly newspaper Canal de Moçambique, referring to the pressure from foreign institutions regarding national policies: "As prime minister, I remember taking decisions, for example, that would be better if I was aware of how the World Bank works. You have a useful period to negotiate with those institutions. But there it is, how long can I survive without money? Because it is the money that I need to implement programs".

Citing another high-level official at the time, Machungo (2013), in an interview in April 2009, spoke about the lack of independence of the country with respect to political decisions at national level: "there were great pressures for an accelerated privatization with the threat of reducing or cutting off external resources".

The World Bank (WB) forced the privatization of the cashew industry because it believed that the liberalization of the cashew nut marketing would benefit the peasant producers with the income increase and consequent incentive to raise the production of the nut, which did not occur. The main argument of the WB was the assumption that the processing industry was being inefficient regarding the added value of the almond/kernel, and that raw cashew nut exports to India accounted for the largest gains in terms of foreign currency against the processed product (kernel). Under these conditions, it was stated that traders/exporters could pay better. The consequences of the liberalization of trade of raw cashew nuts were contrary to World Bank's forecasts, as there were drastic reductions in prices to producers. According to Kanji et. al (2003), the World Bank expected to achieve the following gains with trade liberalization: the reduction of export tariffs on raw nuts, which would increase demand and competition among exporters, and the price to the producer; increase in the number of traders raw of cashew nut by eliminating trade licensing; encourage competition among traders, who would pay higher prices to small producers; and higher price to the producer farmer would increase the incentive to trade and their income.

Leite (I999) states that the trade of cashew nuts represented an important source of foreign currency during the I970s, reaching around $2 \mathrm{I} .3 \%$ of total exports. According to the graphic below, Mozambique occupied the first place in global production of cashew nuts between I96 3 and I977, even supplying around 63\% of the global market in I970. 


\section{Graphic 1: Production of cashew nuts of Mozambique as a percentage of global production}

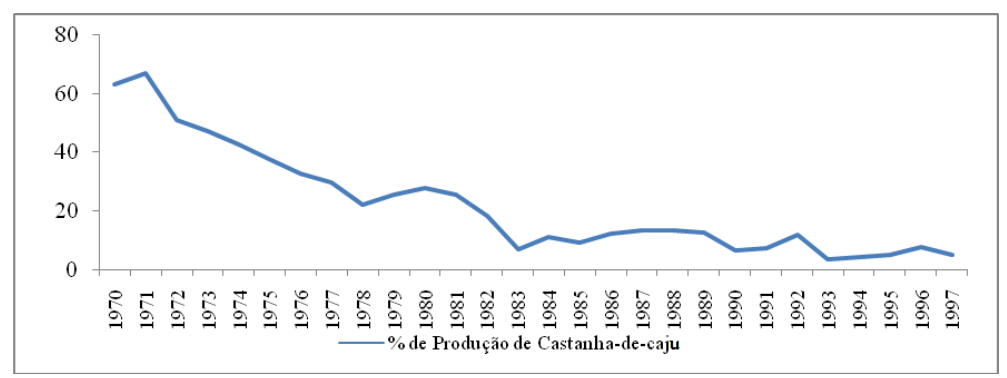

Source: Leite (I999).

\section{Closure of the Border with Southern Rhodesia (Zimbabwe)}

Another decision whose process is analyzed here is the closure of the border with Southern Rhodesia, now Zimbabwe on March 3rd, I976. Southern Rhodesia comprises part of the territory known as the Confederation of Rhodesia whose territories were Nyasaland (now Malawi), Northern Rhodesia (now Zambia) and Southern Rhodesia (now Zimbabwe). Through UN's Resolution I5I4 (UN I960), Malawi and Zambia acceded to independence. It happens that Rhodesia was kept under British domination. Ian Smith, Prime Minister of this territory at the time, decided to proclaim unilateral independence in I965, forming a government of the white minority. It was under this government that the United Nations enacted economic sanctions against the country, during the struggle for national liberation of Mozambique, Zimbabwe African National Union (ZANU) and others nationalist movements in the Southern Africa Region, were fighting for the independence of their territories.

With the end of this struggle and the conquest of independence on June 25, I975, Mozambique studied forms to support the Committee for the Liberation of Africa, and thereby Rhodesia (Zimbabwe). The closure of the border with Southern Rhodesia is the focus of the present approach, and distinct individuals were interviewed during the field work. The key issues regarded the reasons that led Mozambique to take the decision to close the border.

After Rhodesia's unilateral declaration of independence, the United Nations enacted UN Resolution nr 232/1965 (UN I965). Mozambique, follow- 
ing its principles, for example those in UN Resolution $\mathrm{nr}$ 234, adhered to this resolution imposing sanctions against that territory which implied precisely the closure of the border with that country. With this decision, Mozambique experienced severe economic difficulties. According to the interviewees, this decision was preceded by an analysis of the organs of the party and the government. It was noted that Mozambique could not be indifferent after having benefited from the solidarity and support of other peoples during its own struggle for independence.

The sanctions produced an estimated loss of 510 million US Dollars. Respondents say that the United Nations had pledged substantial assistance to alleviate the burden of sanctions; however, this promise was never fulfilled. Merchandise and other goods that were in Mozambican ports bound to that territory were confiscated and traded. Such property, according to the respondents, was traded somewhere in Europe, where a bank account was opened to serve for commercial purposes. That trade yielded 40 million dollars, meaning those goods were mostly exported. An enigma remains to be solved: firstly, why did the United Nations not fulfill its promise?; and, secondly, what became of the 40 million USD deposited in a foreign bank by instruction of the Central Bank?

It is estimated that close to a hundred thousand Mozambicans lost their jobs as a result of sanctions. The third enigma is: how did Mozambicans survive such deprivation of jobs? This time deteriorated relations with that country, having Ian Smith's forces carried out airstrikes against Mozambique, notably the Nhazonia massacre in Manica province, in August 1976, where Zimbabwean refugees were living. Around I,600 citizens were slaughtered on August II, I976 and the bridge on the Pungwe River in the same province was destroyed.

This was not the only massacre. There is another known massacre in Tete province, made by aerial bombardment which had a balance of $\mathrm{I}, 030$ fatalities on November 23, I977. So, on one hand, the sanctions may be seen as a measure to adhere to the Resolution of the United Nations (UN I965), on the other, it can be said that it seems to have hardened the degree of relationship between Mozambique and Rhodesian territory, in particular with Ian Smith's regime. 


\section{Dynamics of Economic and Social Development in the Period 1975-1982}

Samora Machel took the decision to close the border with Zimbabwe, but Zimbabwe's Independence, on April I8th, I980, brought about a peace spectrum. In order to better celebrate this period, which came to respond to the concerns of the Mozambican people, he sought to create the economic bases for development. It is within this context that the government prepared the Prospective Indicative Plan (PPI). This strategic plan intended to improve the standard of living of the population. Between I977 and I98I the country's Global Social Product increased by iı.6\%, a growth that is expressed as follows: the increase in Gross Agricultural Production of 8.8\%; the increase in Gross Industrial Production of $13.7 \%$; the increase in Gross Production of transport and communications of $15.4 \%$; and the increase in Gross Production of construction of $25 \%$ (FRELIMO I983).

It was during this period that central planning was introduced as a system that was intended to regulate and drive the whole process of economic and social development of Mozambique. In this way, about $85 \%$ of the total market production was included in the centralized planning. Through the planning system, the Mozambican workers began to participate in the management of the economy. The state sector of the economy grew and developed during this period. From I975 to I977 dozens of agricultural, livestock, industrial, commercial, and other enterprises were recovered, after having been abandoned and sabotaged by the colonialists in their flight in disarray (FRELIMO I983).

All empirical factors need a theoretical framework. The multifaceted profile of Samora Moisés Machel, regarding his way of being (leadership), fits the following theoretical approaches: a) Theory of personality styles; b) Theory of leadership styles: and c) Contingence. Machel's image was a set of several characters, each of which acted depending on the context. Therefore, all decisions taken by him reflected, in fact, that multifaceted character. Each character was influential in a decision taken by him. Decisions relating to the nationalization, the communal villages, the distribution of weapons to the population (November 5, I982 at the Independence Square in the city of Maputo) and the closure of the border with Southern Rhodesia reflected Samora Machel's form of being.

Therefore, the leadership theories mentioned above and their convergence frame perfectly Samora Machel's profile. Samora Machel was a leader who exercised his leadership with a view to the good of the people, hence 
the reason for systematic interaction with the masses in order to raise issues that affected the people (communicative attitude). The governance form he adopted was based on a centrally-planned economy (emergence of state farms, cooperatives, people's shops, dynamizing groups, travel credentials etc.).

When deciding to distribute weapons to the population, it is noted that it was a leader's decision, drawing guidelines to be obeyed, characterizing an autocratic and rational leadership. The decision to nationalize the buildings was taken collectively by the cabinet, under the influence of Samora Machel, and announced by himself. The closure of the border with Southern Rhodesia fit democratic leadership, in which the leader debates and decides together with his direct collaborators.

The relationship between the leader and the people he led was clear and one of obedience, due to the degree of trust the people had in relation to Samora Machel. This aspect is visible regarding the crowds at the rallies he directed, where the population took the commitment to get organized according to the guidelines set at the level of neighborhoods (block leaders, dynamizing groups) vigilant groups etc. Samora Machel was a leader guided by the principle of social equality. Regarding his leadership style, he was democratic and participatory, which is corroborated by interviews with Hélder Martins (20I4), Sérgio Vieira (20I3), Óscar Monteiro (20I3) and Julio Carrilho (2013), since all of them share the fact that they took part in consultation meetings, firstly in the party, because they were in the Politburo, the Party's highest body ruling between sessions of the Central Committee, and, secondly, in the government, the decision executor.

The bodies consulted discussed the proposals, evaluating the pros and cons, and then decided. Thus, in this literature, this methodology of action underlies a situational leadership. Therefore, the decision on the nationalization of buildings characterizes Samora Machel as being a situational leader because he was in a post-independence context, but the state had no power on land yet, nor on the entire infrastructure generated by the colonial system.

The newly independent people (previously not entitled to benefit from the products of their labor) and the abandoned property generated urgency in decision-making about what to do with that infrastructure. In this perspective, it can be considered that Samora Machel's leadership fits the Blanchard (20I2) perspective of top-level leadership, that is, it is considered a leadership at that level where the decision-maker decides in favor of others, in the case of Samora Machel those "others" were the Mozambican people. 


\section{Table 1: Comparing the Leadership of Samora and Theories of Leadership}

\begin{tabular}{|c|c|c|c|}
\hline $\begin{array}{l}\text { Governance } \\
\text { Decisions }\end{array}$ & Characterization & Role of the leader & $\begin{array}{l}\text { Theory } \\
\text { of leadership }\end{array}$ \\
\hline Nacionalizations & $\begin{array}{l}\text { State had the power } \\
\text { over land, infra- } \\
\text { structure, buildings } \\
\text { and services }\end{array}$ & $\begin{array}{l}\text { Leadership at the } \\
\text { higher level, unify- } \\
\text { ing the decisions }\end{array}$ & $\begin{array}{l}\text { Situational and } \\
\text { contigencial Theory }\end{array}$ \\
\hline Communal Villages & $\begin{array}{l}\text { Provision of ser- } \\
\text { vices to the popula- } \\
\text { tion, infrastructure, } \\
\text { territory planning }\end{array}$ & $\begin{array}{l}\text { Debate, unifying the } \\
\text { decisions }\end{array}$ & $\begin{array}{l}\text { Democratic and } \\
\text { participatory Lead- } \\
\text { ership }\end{array}$ \\
\hline $\begin{array}{l}\text { Distributions } \\
\text { of weapons }\end{array}$ & $\begin{array}{l}\text { Distribution of } \\
\text { weapons to the } \\
\text { population to } \\
\text { defend against } \\
\text { enemy aggression }\end{array}$ & $\begin{array}{l}\text { Decision taken by } \\
\text { the leader as com- } \\
\text { manding chief }\end{array}$ & $\begin{array}{l}\text { Autocratic and } \\
\text { rational Leadership }\end{array}$ \\
\hline $\begin{array}{l}\text { Closure } \\
\text { of the border }\end{array}$ & $\begin{array}{l}\text { Aggression from } \\
\text { South Rhodesia } \\
\text { demanded the clo- } \\
\text { sure of the border }\end{array}$ & $\begin{array}{l}\text { Debate, unifying the } \\
\text { decisions }\end{array}$ & $\begin{array}{l}\text { Democratic and } \\
\text { participatory Lead- } \\
\text { ership }\end{array}$ \\
\hline $\begin{array}{l}\text { Massive } \\
\text { participation } \\
\text { at Rallies }\end{array}$ & Communication & Mobilization & $\begin{array}{l}\text { Charismatic Lead- } \\
\text { ership }\end{array}$ \\
\hline $\begin{array}{l}\text { Sending students } \\
\text { to the Republic } \\
\text { of Cuba }\end{array}$ & $\begin{array}{l}\text { Guarantee the edu- } \\
\text { cation and opportu- } \\
\text { nity to all and rep- } \\
\text { resentation from all } \\
\text { country's districts } \\
\text { was required }\end{array}$ & $\begin{array}{l}\text { Ensure national } \\
\text { unity }\end{array}$ & Geo-leadership \\
\hline
\end{tabular}

Source: Created by the author.

Mazula (20I4) says that Mozambique did not invent the nationalizations, since other countries like the US and Germany had already done that much earlier. And, for him, it was inconceivable that a new country would not have its own infrastructure. In addition, the state itself did not benefit from nationalization, having given everything to the people, which embodies the above. But for Máximo Dias (2014) the decision "was as independence's mishap", that is, he argues that nationalization should not have taken place. According to Carrilho (2013), the idea of nationalization was intended only 
for buildings of cemented areas, which were inhabited by the Portuguese by then. However, realizing the existence in suburban areas of houses rented as private homes by the black population, and being Samora Machel against the "exploitation of man by man", it was decided to include them as well.

In conclusion it is considered that the leadership of Samora Machel was democratic, participatory, charismatic, situational, and contingencial. This decision also fits the thought of Thucydides, quoted by Châtelet $e t$ al. (2000, I7), which states: "Democracy - the best of political regimes, for ensuring equality and private freedoms - requires constant attention of all citizens. It only exists if the leaders that the people choose do not stop, ever, to calculate and to think about its decisions". He further adds that, being democracy a "regime of freedom that leads to large enterprises, it collapses when these are not driven solely by the principle of intelligence, the calculator intellect who, not only prepares prudent strategies, but also aims to not damage or favor any of the constituent groups of the community".

Thus, this decision had a positive economic impact for Mozambicans, as all beneficiaries now have an asset, balancing rural and urban areas, in spite of not everyone having been able to occupy the houses. Regarding the decision on the establishment of communal villages, it was intended to value the experience of freedoms areas and provide basic services to the population, creating infrastructure such as schools, hospitals, roads, and production, as well consumption cooperatives. In terms of organization of the territory, this decision, according to the literature on decision typologies, followed the rational and neo-rational theories, as it was preceded by a debate. From the discussions made, it was decided to create the CNAC, aimed at overseeing and implementing the strategy. So, the idea behind the creation of communal villages was to ensure the welfare of the population, the creation of basic infrastructure, that only existed in the city, around buildings, but not everyone lived in them. It was necessary to bring the infrastructure to the countryside.

Therefore, it was a delicate challenge because the population that had assets, such as cattle, and thought that by going to the communal villages these assets would be lost. On the other hand, the communal village was seen as an opportunity for many, it may be said that Samora had a Universalist vision of well-being for the entire people. Finally, regarding the decision to close the borders with Southern Rhodesia, the following is highlighted: FRELIMO, in its Bylaw and Program, approved in the first Congress in 1962, established as one of its duties to support the struggle of colonized peoples, that is, solidarity with those peoples; FRELIMO was supported by Tanzania and the Committee for the Liberation of Africa; the need for reciprocity to a 
people who had previously supported FRELIMO; UN's Resolution I5I4 of December I4, I960, which determined the right to self-determination and independence of colonized peoples; and the Resolution 234 (UN ig65) of the United Nations, which imposed sanctions against Southern Rhodesia, in the face of the unilateral declaration of independence by the white minority, represented by its Prime Minister Ian Smith.

These may be the reasons that prompted this decision and the need to accelerate the process of independence of the black majority. The nature of this decision, in view of the literature, converges with the top-level decision, because Samora Machel and the people of Mozambique, did not benefit from the decision. That is to say that this decision covers the type presented by author Blanchard (2012), in the sense that it has combined evidence of rational and neo-rational types.

But the biggest disappointment is the fact that the United Nations promised to compensate the country for closing the border, which was never fulfilled. The repercussion of this process was the issue of the cashew sector, which was once state-owned, and was then privatized and later liberalized. This decision for liberalization, required by the WB and the International Monetary Fund, was a condition to receive funding. According to Patel (2013), it was not understandable that the Mozambican leadership accepted this demand, which implied the unemployment of Io,ooo Mozambicans, and led to the closure of the cashew industry, which was one of the revenue sources for the rural population.

This decision to unemploy Mozambicans does not fit a level, since it is not entirely clear who were the beneficiaries from it. That is, in this literature there are signs of benefits to decision-makers, and signs of a lower-level leadership. With the industry paralyzed, producers could not meet the expectations created, which along with the destabilizing factor of war, led to the failure of the project.

\section{Conclusion}

Samora Machel's leadership dynamics was multifaceted, with the main desideratum to meet the needs of the people, through the nationalizations and communal villages. Samora was the geo-leader and cultural leader. The Literature can conclude that Samora Machel's leadership style and the features are studied by various scholars. Samora Machel played toplevel leadership that is verified by the decision of nationalization, creation 
of communal villages, and closure of the border with Southern Rhodesia, from which there were no benefits, a fact revealed by the author's experience.

In fact, he was a strategic leader for the nature of the decisions and their consequences. At some point Samora was a charismatic leader, in view of this literature and of the evidence collected where he appears in rallies to speak to crowds. Samora Machel can be considered a geo-leader in the perspective that he respected ethnic differences especially in the selection of guerrillas sent for training abroad, as well as in the post-independence when students were selected to go to Cuba, moments in which he would ensure representativeness of all the country's districts. Next, the main ideological-political and economic motivations for decision-making are described, their origin considering the need to meet FRELIMO's program expectations, as approved in 1962 , that, in addition to the conquest of independence, included building one developed Mozambique, industrial and prosperous. The study considers this to be one of the reasons for those decisions.

Comparing the economic and social effects of Samora Machel's leadership's decisions, it appears that the nationalizations were an important step in that it allowed Mozambicans to obtain an asset out of nowhere (independence). However, to the national stakeholders this decision represented loss as they lost their livelihood sources. There are evidences that underlie the action of the Samora Machel leadership that all decision-making processes were preceded by a debate in the different organs, namely the Cabinet, the Political Bureau and Political Military Committee. In this respect it can be considered that these cases, according to this literature in this study, there was democratic leadership. The decisions were influenced, on one hand, by the process of the national liberation struggle that brought the leadership experience in the liberated zones, and, on the other hand, by the great expectation and euphoria created by the conquest of independence after centuries of colonial domination.

In the face of this study, it is recommended that a future study should: determine the fate of the 40 million dollars that resulted from transactions of confiscated property, when the borders with Southern Rhodesia were closed; investigate the reasons for the non-fulfillment by the United Nations of its promises; and know how the I००,000 Mozambicans who lost their jobs, due to the closure of borders, survived from the March 3, 1976, date of the border's closure, to April I8, I980, date of Zimbabwe's independence and the consequent re-opening of the border. 


\section{References}

Bennis, Warren et al. 2004. A Essência da Liderança. II ${ }^{a}$ Edição. Rio de Janeiro: Sextante.

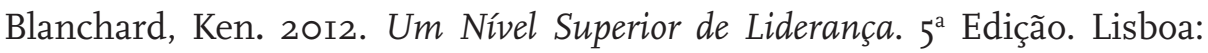
Conjuntura Actual Editora, S.A.

Carrilho, Júlio. 2013. Minister for Public Works and Housing in the First Government of the Republic. Interview Conducted in the Preparation of a Doctoral Thesis entitled "Leadership and Decision Processes in Mozambique" Presented in Commonwealth Open University. Maputo, Interviewed in July, 20I3.

Châtelet, François, Olivier Duhamel and Evelyne Pisier-Kouchner. 2000. História das Ideias Políticas. Rio de Janeiro: Jorge Zahar.

Christie, Iain. I996. Samora: Uma Biografia. Maputo: Ndjira.

Departamento de Trabalho Ideológico (DTIP). I978. Documents of II National Conference of the Ideological Work. Beira: FRELIMO.

Dias, Máximo. 20I4. Interview Conducted in the Preparation of a Doctoral Thesis entitled "Leadership and Decision Processes in Mozambique" Presented in Commonwealth Open University. Maputo, Interviewed on 28 October, 2014.

Dos Muchangos, Aniceto. I999. MOÇAMBIQUE: Paisagens e Regiões Naturais. República de Moçambique: Tipografia Globo, Lda.

Frente de Libertação de Moçambique (FRELIMO). I976. Documentos da $8^{\text {a }}$ Sessão do Comité Central da FRELIMO. Maputo: Tempo. . I976. FRELIMO's Central Committee Report. Maputo: FRELIMO. . I983. Relatório do Comité Central ao IV Congresso, Colecção $4^{\circ}$ Congresso. Maputo: CEGRAF.

. I983. Directivas Económicas e Sociais, Colecção 4 Congresso. Maputo: CEGRAF.

Kanji, Nazneen, Carin Vijfhuizen, Carla Braga and Luis Artur. 2003. "Liberalization, Gender and Livelihoods: the Mozambique Cashew Nut Case". International Institute for Environment and Development (IIED). Working Paper. Mozambique Phase 2: The South, January-December: I-28.

Leite, Joana. P. I999. "A Guerra do Caju e as Relações Moçambique-Índia na Época Pós-Colonial”. Instituto Superior de Economia e Gestão (CEsA). Documentos de Trabalho n ${ }^{\circ}$ 57: I-47. 
Machungo, Mário. 2013. Interview Conducted in the Preparation of a Doctoral Thesis entitled "Leadership and Decision Processes in Mozambique” Presented in Commonwealth Open University. Maputo, Interviewed on 9 August, 20I3.

Martins, Hélder. 20I4. Interview Conducted in the Preparation of a Doctoral Thesis entitled "Leadership and Decision Processes in Mozambique" Presented in Commonwealth Open University. Maputo, Interviewed on 26 January, 2014.

Mazula, Brazão. 20I4. Interview Conducted in the Preparation of a Doctoral Thesis entitled "Leadership and Decision Processes in Mozambique" Presented in Commonwealth Open University. Maputo, Interviewed on 26 November, 2014.

Medeiros, Carlos Alberto. I989. "Aldeias Comunais em Moçambique". FINISTERRA - Revista Portuguesa de Geografia 24, no. 48: 336-340.

Mocumbi, Pascola. 2013. "Discurso do ex-Primeiro-Ministro Pascoal Mocumbi”. Jornal Semanário Canal de Moçambique. Maputo, 23 de Agosto, 20I3.

Monteiro, José Óscar. 2013. Interview Conducted in the Preparation of a Doctoral Thesis entitled "Leadership and Decision Processes in Mozambique" Presented in Commonwealth Open University. Maputo, Interviewed on 8 October, 2013.

Mosca, João. 20II. Políticas Agrárias de (em) Moçambique (1975-2009). Maputo: Escolar Editora.

Patel, Kekobad M. 20I3. Interview Conducted in the Preparation of a Doctoral Thesis entitled "Leadership and Decision Processes in Mozambique" Presented in Commonwealth Open University. Maputo, Interviewed in July, 20I3.

People's Republic of Mozambique. 1978. Presidential Decree nr. 1/78 of March. Maputo: Imprensa Nacional.

. I979. Decree $n r$ 8/79, 30 June. Maputo: Imprensa Nacional. . 1976. Decreto-lei $n^{\circ} 5 / 76$ de 5 de Fevereiro. Maputo: Imprensa Nacional.

Ribeiro, Darcy. I995. O Povo Brasileiro: A formação e o sentido do Brasil. $2^{\mathrm{a}}$ edição. Curitiba: Companhia das Letras.

Tempo. I976. “Aldeias Comunais”. Revista Tempo. 22 de Fevereiro. Maputo: Tempo: 52-59. 
. 1977. "Aldeias Comunais: Presente e o Futuro". Revista Tempo, 2I de Agosto. Maputo: Tempo, I977: 42-47.

United Nations Organization - UNO. I960. UN's Resolution nr 1514. New York: United Nations.

. I965. Resolution $n r$ 232. New York: United Nations.

. I965. Resolution nr 234. New York: United Nations.

Veloso, Jacinto. 20I3. Interview Conducted in the Preparation of a Doctoral Thesis entitled "Leadership and Decision Processes in Mozambique" Presented in Commonwealth Open University. Maputo, Interviewed on 9 November, 2013.

Vieira, Sérgio. 20I3. Interview Conducted in the Preparation of a Doctoral Thesis entitled "Leadership and Decision Processes in Mozambique" Presented in Commonwealth Open University. Maputo, Interviewed in July, 2013.

\section{ABSTRACT}

This article discusses the leadership and decision-making processes and it has Samora Machel, I975-1986, as the reference. In the introduction, the questioning, motivation, and the structure of the chapters are presented. The article has a theoretical framework that addresses the aspects of the theory of leadership, including issues such as top-level leadership, situational, contingencies, group processes, and organizational systems. It also discusses personality traits of leadership and leadership styles: charismatic leadership, transactional leadership, and transformational leadership. Concepts and approaches to decision making and decision-making types, such as model making, and the rational, bureaucratic, organized anarchy, and neo-rational models are presented. In this study, Samora Machel is seen as a charismatic leader, which is sustained by the massive presence of people in his rallies. He can also be considered as a dialoguing leader. The following are important decisions made by Samora Machel, which are considered in this study: the nationalization of buildings, the communal villages, the Prospective Indicative Plan (PPI) and the closure of the border with Southern Rhodesia, now Zimbabwe.

\section{KEYWORDS}

Leadership; Decision Making Processes; Samora Machel; Mozambique. 